\title{
APTITUDE TREATMENT INTERACTION TERHADAP KEMAMPUAN PEMAHAMAN MATEMATIS SISWA
}

\author{
Yoga Pamungkas ${ }^{1}$ \\ STKIP Garut \\ Ekasatya Aldila Afriansyah ${ }^{2}$ \\ STKIP Garut \\ E-mail : e_satya@yahoo.com
}

\begin{abstract}
ABSTRAK
Kemampuan pemahaman yang menjadi salah satu bagian penting justru faktanya masih rendah. Telah banyak berbagai studi, baik dari skala nasional maupun pada skala internasional yang menunjukkan bahwa prestasi Indonesia terutama dalam pemahaman masih sangat memprihatinkan. Dalam tes yang dilaksanakan Trends In International Mathematics an Science Study (TIMSS), peserta Indonesia masih lemah dalam menyelesaikan soal-soal yangberkaitan dengan mengaplikasikan objek, menjelaskan keterkaitan konsep, menggunakan, memanfaatkan, dan memilih prosedur atau operasi tertentu. Hal tersebut berkaitan dengan pemahaman konsep matematis siswa, maka hasil dari TIMSS dapat menunjukan masih rendahnya pemahaman konsep matematis siswa yang dimiliki oleh siswa SMP di Indonesia. Pada penelitian ini menggunakan metode eksperimen, sebagai populasinya yaitu siswa siswa kelas VIII SMP Negeri 1 Tarogong Kidul tahun ajaran 2015/2016. Pada penelitian ini terpilih kelas eksperimen 1 yaitu kelas VIIIE yang pembelajarannya menggunakan Aptitude Treatment Interaction sedangkan kelas kontrolyaitu kelas VIIB yang pembelajarannya menggunakan Pembelajaran konvensional. Desain penelitian ini yaitu pretest-posttest dengan instrumen penelitian tipe uraian. Berdasarkan hasil analisis data dan pengujian hipotesis, "Terdapat perbedaan kemampuan pemahaman konsep matematis siswa yang mendapat model pembelajaran Aptitude Treatment Interaction dengan siswa yang mendapat model pembelajaran konvensional, sehingga dapat disimpulkan bahwa model pembelajaran Aptitude Treatment Interactionpada penelitian ini telah berpengaruh positif terhadap pembelajaran".
\end{abstract}

Kata Kunci :Trends In International Mathematics an Science Study, Kemampuan Pemahaman Matematis, Aptitude Treatment Interaction, Metode Eksperimen

\section{PENDAHULUAN}

Matematika merupakan salah satu ilmu dasar yang digunakan di segala bidang ilmu pengetahuan dan sangat erat kaitannya dengan kehidupan sehari-hari. Dua puluh tahun lalu, National Research Council (NRC) dari Amerika Serikat telah menyatakan pentingnya matematika bagi kehidupan manusia denganpernyataan berikut: "Mathematics is the key to 
opportunity" matematika adalah kunci ke arah peluang-peluang. Bagi seorang siswa keberhasilan mempelajari matematika akanmembuka pintu karir yang cemerlang (Nuryadin, 2013: 1).

Sedangkan dalam tujuan pembelajaran terdapat beberapa aspek kemampuan salah satunya kemampuan pemahaman matematis. Dalam pembelajaran matematika pemahaman merupakan aspek yang sangat penting.Pemahaman matematis merupakan landasan penting untuk siswa berpikir dalam menyelesaikan persoalan-persoalan matematika maupun persoalan-persoalan di kehidupan sehari-hari.

Namun disayangkan, kemampuan pemahaman yang menjadi salah satu bagian penting justru faktanya masih rendah.Telah banyak berbagai studi, baik dari skala nasional maupun pada skala internasional yang menunjukkan bahwa prestasi Indonesia terutama dalam pemahaman masih sangat memprihatinkan.Pada tahun 2011, Indonesia hanya mampu mengumpulkan 386 point dari skor rata-rata 500 point. Dalam tes yang dilaksanakan Trends In International Mathematics an Science Study (TIMSS), peserta Indonesia masih lemah dalam menyelesaikan soal-soal yangberkaitan dengan mengaplikasikan objek, menjelaskan keterkaitan konsep, menggunakan, memanfaatkan, dan memilih prosedur atau operasi tertentu. Hal tersebut berkaitan dengan pemahaman konsep matematis siswa, maka hasil dari TIMSS dapat menunjukan masih rendahnya pemahaman konsep matematis siswa yang dimiliki oleh siswa SMP di Indonesia (Herdiana, 2015: 4).

Dalam mengatasi permasalahan diatas, para guru dan pendidik harus memerlukan model pengajaran yang inovatif. Adapun salah satu model pembelajaran yang dapat dijadikan alternatif oleh guru dalam mangajar yaitu model pembelajaranAptitude Treatment Interaction.

Aptitude Treatment Interaction (ATI) approach adalah sebuah model yang berusaha mencari dan menemukan perlakuan-perlakuan (treatment) yang cocok dengan perbedaan (aptitude) kemampuan siswa, yaitu perlakuan (treatments) yang secara optimal diterapkan untuk siswa yang berbeda tingkat kemampuannya. Model pembelajaran ATI akan efektif digunakan untuk pembelajaran yang kemampuan individu siswanya beragam, karena model pembelajaran ATI merupakan suatu konsep atau model yang berisikan sejumlah strategi pembelajaran (treatment) yang efektif digunakan untuk siswa tertentu sesuai dengan perbedaan kemampuan (aptitude)-nya (Syafruddin, 2005:37).

\section{Rumusan Masalah}

Berdasarkan latar belakang di atas, maka dapat dirumuskan permasalahan sebagai berikut 
1. Apakah terdapat pengaruh model pembelajaran Aptitude Treatment Interaction terhadap kemampuan pemahaman matematis siswa?

2. Bagaimana interpretasi peningkatan kemampuan pemahaman matematis siswa yang mendapatkan pembelajaran model pembelajaran Aptitude Treatment Interaction dan model pembelajaran Konvensional?

3. Bagaimana interpretasi sikap siswa terhadap model pembelajaran Aptitude Treatment Interaction?

\section{Tinjauan Pustaka}

\section{Kemamapuan Pemahaman Matematis}

Pemahaman merupakan terjemahan dari istilah understanding yang diartikan sebagai penyerapan arti suatu materi yang dipelajari.Dalam kamus besar Bahasa Indonesia, paham berarti mengerti dengan tepat, sedangkan konsep berarti suatu rancangan.Sedangkan dalam matematika, konsep adalah suatu ide abstrak yang memungkinkan seseorang untuk menggolongkan suatu objek atau kejadian.Jadi pemahaman konsep adalah pengertian yang besar tentang suatu rancangan atau ide abstrak.

kemampuan pemahaman matematis yang di gunakan dalam penelitian ini adalah kemampuan pemahaman menurut Skemp, yaitu:

Skemp membedakan dua jenis tingkat pemahaman, yaitu sebagai berikut:

1. Pemahaman instrumental yaitu: hafal sesuatu secara terpisah atau dapat menerapkan sesuatu pada perhitungan rutin atau sederhana, mengerjakan sesuatu secara algoritmik saja. Tingkat pemahaman ini setara dengan pemahaman mekanikal.

2. Pemahaman rasional yaitu: dapat mengaitkan sesuatu dengan hal lain secara benar dan menyadari proses yangdilakukan. Tingkat pemahaman ini setara dengan pemahaman rasional.

\section{Model Pembelajaran Aptitude Treatment Interaction (ATI)}

Aptitude Treatment Interaction (ATI) approach adalah sebuah model yang berusaha mencari dan menemukan perlakuan-perlakuan (treatment) yang cocok dengan perbedaan (aptitude) kemampuan siswa, yaitu perlakuan (treatments) yang secara optimal diterapkan untuk siswa yang berbeda tingkat kemampuannya. Model pembelajaran ATI akan efektif digunakan untuk pembelajaran yang kemampuan individu siswanya beragam, karena model pembelajaran ATI merupakan suatu konsep atau model yang berisikan sejumlah strategi pembelajaran (treatment) yang efektif digunakan untuk siswa tertentu sesuai dengan perbedaan kemampuan (aptitude)-nya (Syafruddin, 2005:37). 
Model ini dapat digunakan karena pembelajaran tidak berpusat pada guru, tetapi siswa bisa lebih aktif dalam pembelajaran sertamenimbulkan motivasi pada siswa, karena tumbuhnya rasa menyelidiki. Menurut Ruseffendi (2006:330) "pentingnya menemukan sesuatu oleh sendiri dapat menumbuhkan rasa percaya diri, meningkatkan motivasi dan dapat menumbuhkan sikap positif terhadap matematika".Sehingga diharapkan kemampuan pemahaman matematis siswa dalam memahami konsep materi dapat meningkat.

\section{METODE PENELITIAN}

\section{Sampel dan Populasi}

Populasi dalam penelitian ini adalah siswa kelas VIII SMP Negeri 1 Tarogong Kidul tahun ajaran 2015/2016.Kemudian sampelnya dipilih secara acak, yaitu kelas VIII-E sebagai kelas eksperimen dan kelas VIII-B sebagai kelas kontrol.

\section{Waktu dan Tempat Penelitian}

Waktu penelitian ini dilaksanakan pada semester genap tahun ajaran 2015/2016 pada tanggal 29 Maret - 26 April 2016.Adapun tempat pelaksanaan penelitian di SMP Negeri 1 Tarogong Kidul.

\section{Desain Penelitian}

Desain Desain penelitian yang digunakan dalam penelitian ini yaitu desain menurut Rahadi (2008);

$\begin{array}{ccc}\text { O } & \text { X } & \text { O } \\ --------- & \text { O }\end{array}$

Keterangan :

O : Tes awal (pre-test) dan tes akhir (post-test)

$\mathrm{X} \quad$ : Pembelajaran dengan menggunakan model pembelajaranAptitude

\section{TreatmentInteraction}

\section{Teknik Pengumpulan Data dan Analisis Data}

Dalam penelitian ini, teknik pengumpulan data yang digunakan adalah teknik tes (test) kemampuan pemahaman matematis dan tes skala sikap siswa terhadap kegiatan pembelajaran. Sedangkan instrumen penelitian yang digunakan adalah soal tes subjektif yang pada umumnya berbrntuk uraian/esai serta lembar angket. Tes uraian digunakan pada saat pretest dan posttest sedangkan lembar angket di isi setelah dilaksanakan posttest. 


\section{HASIL DAN PEMBAHASAN}

\section{Deskripsi Data Hasil Penelitian}

Berikut ini adalah hasil deskripsi tes awal dan tes akhir kemampuan pemahaman matematis siswa kelas ATI dan kelas Konvensional yang disajikan pada tabel berikut :

Tabel 1. Rekapitulasi Hasil Analisis Data

\begin{tabular}{|c|c|c|c|c|c|}
\hline \multirow{2}{*}{ Kelas } & \multicolumn{5}{|c|}{ Kelas ATI } \\
\cline { 3 - 6 } & $\mathrm{N}$ & $\mathrm{Xmax}$ & $\mathrm{Xmin}$ & $\mathrm{X}$ & $\mathrm{S}$ \\
\hline Pretes & \multirow{3}{*}{35} & 5 & 1 & 3,57 & 1,04 \\
\cline { 3 - 6 } Posttest & & 20 & 5 & 17,8 & 3,65 \\
\hline \multirow{2}{*}{ Kelas } & \multicolumn{5}{|c|}{ Kelas Konvensional } \\
\cline { 3 - 6 } & $\mathrm{N}$ & $\mathrm{Xmax}$ & Xmin & $\mathrm{X}$ & $\mathrm{S}$ \\
\hline Pretes & \multirow{2}{*}{35} & 5 & 0 & 2,14 & 1,22 \\
\hline Posttest & & 10 & 4 & 7,77 & 1,8 \\
\hline
\end{tabular}

\section{Analisis Statistik dan Uji Hipotesis}

\section{a. Analisis Data Pretest}

Dari tabel di atas menunjukan bahwa skor rata-rata kemampuan awal pemahaman matematis siswa pada kelas ATI adalah 3,57 dan skor ideal 20 dengan simpangan baku 1,04 sedangkan skor rata-rata kemampuan awal pemahaman matematis siswa pada kelas Konvensional adalah 2,14 dan skor ideal 20 dengan simpangan baku 1,22. Setelah dilakukan uji normalitas, ternyata salah satu kelas yaitu kelas ATI berdistribusi tidak normal, maka dilanjutkan dengan uji mann whitney pada tarap signifikasi $1 \%$ dan di peroleh kesimpulan bahwa terdapat perbedaan kemampuan awal pemahaman matematis sebelum pembelajaran antara siswa kelas ATI dan kelas Konvensional.

\section{b. Analisis Data Posttest}

Dari tabel di atas menunjukan bahwa skor rata-rata kemampuan akhir pemahaman matematis siswa pada kelas ATI adalah 17,8 dan skor ideal 20 dengan simpangan baku 3,65 sedangkan skor rata-rata kemampuan awal pemahaman matematis siswa pada kelas Konvensional adalah 7,77 dan skor ideal 20 dengan simpangan baku 1,8. Setelah dilakukan uji normalitas, ternyata salah satu kelas yaitu kelas ATI berdistribusi tidak normal, maka dilanjutkan dengan uji mann whitney pada tarap signifikasi $1 \%$ dan di peroleh kesimpulan bahwakemampuan pemahaman matematis siswa yang mendapatkan model pembelajaran ATI lebih tinggi daripada kemampuan pemahaman matematis siswa yang mendapatkan model pembelajaran konvensional. Artinya, model pembelajaran ATIberpengaruh positif terhadap kemampuan pemahaman matematis siswa. 


\section{c. Analisis Data Peningkatan Kemampuan Pemahaman Matematis Siswa}

Dari hasil perhitungan diperoleh nilairata-rata skor hitung dari kelas ATI dan kelas Konvensional, yaitu :

Tabel 2. Hasil Analisis Data Gain

\begin{tabular}{|c|c|c|c|}
\hline Kelas & $\begin{array}{c}\text { Banyak } \\
\text { Data }\end{array}$ & Rerata & Interpretasi \\
\hline ATI & 35 & 0,87 & Tinggi \\
\hline Konvensional & 35 & 0,31 & Sedang \\
\hline
\end{tabular}

Berdasarkan Tabel diatas diperoleh rata-rata skor hitung untuk kelas ATI adalah 0,87 dan berinterpretasi tinggi. Sedangkan rata-rata untuk kelas Konvensional adalah 0,31 dan beriterpretasi sedang.

\section{d. Analisis Data Angket}

\section{1) Sikap Siswa Secara Umum}

Berdasarkan perhitungan analisis angket diperoleh skor total kelas eksperimen sebesar 3181 dan skor tersebur disesuaikan dengan tabel dan dapat disimpulkan bahwa skala sikap kelas eksperimen secara umum mengenai sikap siswa terhadap model pembelajaran ATI berinterpretasi baik.

\section{2) Sikap Siswa Tiap Individu}

Berdasarkan perhitungan analisis angket untuk tiap individu diperoleh siswa yang berinterpretasi sangat baik sebanyak 34\%, berinterpretasi baik sebanyak 54\%, dan berinterpretasi cukup sebanyak $12 \%$.

\section{3) Sikap Siswa Tiap Indikator}

Berdasarkan hasil perhitungan analisis angket diperoleh hasil sebagai berikut :

Tabel 3. Hasil Analisis Data Angket

\begin{tabular}{|c|c|}
\hline Indikator Angket & Interpretasi \\
\hline 1. Menunjukan kesukaan terhadap pelajaran matematika & Baik \\
\hline 2. Menunjukan keseriusan belajar & Baik \\
\hline 3. Menunjukan keinginan berpartisipasi dalam diskusi kelas & Baik \\
\hline $\begin{array}{l}\text { 4. Menunjukan kesukaan terhadap pelajaran matematika dengan menggunakan model pembelajaran } \\
\text { Aptitude Treatment Interaction (ATI) }\end{array}$ & Baik \\
\hline $\begin{array}{l}\text { 5. Menunjukan aktivitas selama proses pembelajaran melalui model pembelajaran Aptitude Treatment } \\
\text { Interaction (ATI) }\end{array}$ & Baik \\
\hline 6. Pandangan siswa terhadap penyajian Lembar Kegiatan Siswa (LKS) & Baik \\
\hline 7. Menunjukan manfaat menguasai terhadap soal-soal yang diberikan & Baik \\
\hline 8. Menunjukan kesukaan terhadap soal-soal yang diberikan & Baik \\
\hline 9. Menunjukan kesungguhan dalam menyelesaikan soal-soal yang diberikan & Baik \\
\hline
\end{tabular}




\section{Pembahasan}

Hasil aanalisis terhadap rata-rata skor tes akhir (posttest) pada kelas ATI dan kelas Konvensional, ternyata disimpulkan kemampuan pemahaman matematis siswa yang mendapatkan model pembelajaran ATI lebih tinggi daripada siswa yang mendapatkan model pembelajaran Konvensional. Hal ini dapat dilihat dari skor rata-rata posttest yaitu rata-rata kelas ATI sebesar 17,8 sedangkan rata-rata kelas Konvensional sebesar 7,77 dengan selisih rata-rata kedua kelas sebesar 10,03. Artinya, model pembelajaran ATI berpengaruh positif terhadap kemampuan pemahaman matematis siswa.

Dilakukan pula analisis terhadap data pretest dan posttest kelas ATI dan kelas Konvensional dengan menggunakan uji gain, dan diperoleh rata-rata gain untuk kelas ATI sebesar 0,87 sedangkan rata-rata gain untuk kelas Konvensional sebesar 0,31.

Dari hasil penelitian diperoleh bahawa kelas ATI berpengaruh positif pada kemampuan pemahaman matematis siswa, hal ini dapat dilihat dari nilai rata-rata pada tes akhir kemampuan pemahaman matematis kelompok ATI yaitu 17,8 lebih besar dibandingkan dengan model pembelajaran Konvensional yaitu 7,77. Hasil temuan ini lebih memperkuat dan melengkapi temuan Widiastuti (2014) yang menyimpulkan bahwa model pembelajaran ATI dapat meningkatkan kemampuan pemahaman matematis siswa.

Faktor-faktor yang dapat menjadi penyebab adanya perbedaan rata-rata kemampuan pemahaman matematis antara siswa yang mendapatkan model pembelajaran ATI dengan siswa yang mendapatkan model pembelajaran Konvensional adalah sebagai berikut:

1. Mengawali pembelajaran dengan melaksanakan pengukuran kemampuan masing-masing siswa melalui tes. Hal ini dilakukan guna untuk mendapatkan data yang jelas tentang karakteristik kemampuan (aptitude) siswa. Setelah itu membagi atau mengelompokkan siswa menjadi tiga kelompok sesuai dengan klasifikasi yang didapatkan dari hasil tes. Pengelompokan siswa tersebut diberi label tinggi, sedang dan rendah.Memberikan perlakuan (treatment) kepada masing-masing kelompok (tinggi, sedang dan rendah) dalam pembelajaran disesuaikan dengan pokok bahasan yang akan diberikan. Melalui lembar kerja siswa, guru membantu siswa memahami setting masalah, konteks matematis, dan tantangan. Dalam fase ini juga memungkinkan guru untuk mengantarkan ide-ide baru, mengklarifikasi definisi, meninjau ulang konsep lama, dan mengaitkan masalah untuk pengalaman siswa sebelumnya (treatment).

2. Pembelajaran dilakukan sesuai dengan kelompok yang diberikan, bagi kelompok siswa yang memiliki kemampuan (aptitude) tinggi, perlakuan (treatment) yang diberikan yaitu belajar mandiri (self learning) dengan menggunakan modul atau buku-buku yang relevan. 
Bagi kelompok siswa yang berkemampuan sedang atau rendah diberikan pembelajaran regular atau pembelajaran konvensional sebagaimana biasanya. Dan bagi kelompok siswa yang mempunyai kemampuan rendah diberikan special treatment, yaitu berupa pembelajaran dalam bentuk re-teaching dan tutorial.

3. Melalui pembelajaran ATI pembelajaran menjadi lebih menarik dikarenakan ada kaitannya dengan kehidupan sehari-hari dan benda nyata sehingga siswa menjadi semangat dan termotivasi dalam kegiatan belajar mengajar. Indikator meningkatnya semangat siswa tersebut adalah keaktifan siswa dalam menyampaikan pendapat hasil diskusi danmenanggapi pendapat temannya.

\section{SIMPULAN DAN SARAN}

\section{Kesimpulan}

Berdasarkan hasil pengolahan data dan temuan yang di peroleh dalam penelitian ini, maka dapat disimpulkan bahwa :

a. Kemampuan pemahaman matematis antara siswa yang mendapatkan model pembelajaran ATI lebih tinggi dari pada siswa yang mendapatkan model pembelajaran Konvensional. Artinya, model pembelajaran ATI berpengaruh positif terhadap kemampuan pemahaman matematis siswa.

b. Peningkatan kemampuan pemahaman matematis siswa yang mendapatkan model pembelajaran ATI interpretasinya tergolong tinggi dan model pembelajaran Konvensional interpretasinya tergolong sedang.

c. Sikap siswa yang mendapatkan model pembelajaran ATI menunjukan dalam interpretasi baik.

\section{Saran}

Berdasarkan temuan penelitian yang penulis lakukan, penulis memberikan saran-saran sebagai berikut:

a. Model pembelajaranATI bisa digunakan pada pembelajaran karena terbukti dapat meningkatkan kemampuan pemahaman matematis siswa dan kepada guru disarankan untuk memperbanyak memberikan soal-soal pemahaman matematis kepada siswa.

b. Kepada siswa disarankan untuk memperbanyak latihan soal-soal pemahaman sehingga kemampuan pemahaman matematisnya dapat meningkat dan setelah model pembelajaran ini diterapkan, siswa disarankan untuk lebih aktif dalam proses pembelajaran sehingga dapat menumbuhkan prestasi yang baik.

c. Penulis menyarankan pada peneliti selanjutnya agar penelitian menggunakan model pembelajaran ATI tidak hanya berfokus pada kemampuan pemahaman matematis saja, 
tetapi pada kemampuan matematis yang lainnya, seperti: kemampuan komunikasi, kemampuan pemecahan masalah, kemampuan berfikir kritis dan lain-lain yang berhubungan dengan model pembelajaran ATI serta bukan hanya terfokus pada kemampuan matematisnya saja tetapi harus memenuhi kriteria ketuntasan belajar.

d. Sesuai dengan batasan masalah dalam penelitian ini, sehingga hasil penelitian ini hanya berlaku bagi SMP Negeri 1 Tarogong Kidul dengan pokok bahasan bangun ruang kubus dan balok, penulis menyarankan kepada peneliti selanjutnya untuk meneliti dalam ruang lingkup yang lebih luas. Hal ini dimaksudkan agar hasil temuan lebih umum. Selain dari itu penulis menyarankan agar semua aspek dalam pemahaman bisa digunakan sehingga penelitian yang dilakukan dapat menghasilkan hasil yang optimal untuk mengukur kemampuan pemahaman matematis siswa.

\section{DAFTAR PUSTAKA}

Herdiana, E (2015).Perbedaan Kemampuan Pemahaman Konsep Matematis Siswa Antara yang Mendapatkan Project Based Learning dengan yang Mendapatkan Discoveri Learning.Skripsi Matematika STKIP Garut.

Nuryadin, I. (2013).Perbedaan Kemampuan Pemecahan Masalah Matematis Antara Siswa yang Mendapatkan Model CORE (Connecting, Organizing, Reflecting, Extending) Berbasis Multimedia Model CMT (Connected Mathematics Task). Skripsi Pada Jurusan Pendidikan Matematika STKIP Garut: Tidak diterbitkan.

Rahadi, M. (2008).Diktat Kuliah Evaluasi PHPM. STKIP Garut: Tidak diterbitkan.

Syafrudin, N. (2005). Model Pembelajaran yang Memperhatikan Keragaman Individu Siswa dalam Kurikulum Berbasis Kompetensi. Ciputa: Quantum Teaching. 